\title{
Uma mulher e suas emoções: o diário de Eugénie Leuzinger Masset (1885-1889)*
}

\author{
Vavy Pacheco Borges**
}

\begin{abstract}
Resumo
Uma breve discussão sobre o diário enquanto prática é sucedida pelo diário de uma mulher do século XIX, analisado enquanto sintoma/remédio após a morte de seu marido. A partir de suas características de origem, educação, cultura e religião, essa narrativa apresenta os conflitos de uma mulher que se vê obrigada a lidar com dificuldades econômicas - tendo que assumir a vida pública e profissional para manter os filhos - $e$ com a saudade de uma profícua relação amorosa.
\end{abstract}

Palavras-chave: Diário, Mulheres, Imagem, Emoções, Século XIX.

\footnotetext{
" Recebido para publicação em agosto de 2002.

*** Professora Doutora do Departamento de História, Instituto de Filosofia e Ciências Humanas, Unicamp.
} 
Uma mulher e suas emoções

A Woman and her Emotions:

The Diary of Eugénie Leuzinger Masset (1885-1889)

\begin{abstract}
After a breef discussion on diary as a practice, the article discribes the diary of a $19^{\text {th }}$ century woman, analysing it as symptom of/ remedy for her distress after her husband's death. Her origin, education, culture and religion are shown in the diary. This narrative shows the conflicts caused by her economic problems heading her to enter public and professional life, for the maintenance of her children - and the feeling of lonliness after a wonderful love relationship.
\end{abstract}

Key Words: Diary, Women, Image, Emotions, $\mathrm{XIX}^{\text {th }}$ Century. 
Vavy Pacheco Borges

\section{O diário como prática}

Não é um caso raro esse diário de uma mulher do século XIX. Sua autora é uma mulher que faz parte de uma família de origem européia, vivendo no Rio de Janeiro, então sede da corte brasileira. O diário revela suas características de origem, educação e cultura, além de mostrá-la uma católica fervorosa. ${ }^{1}$

A preocupação com o diário está ligada ao campo da literatura e da noção de pessoa como esta aparece na escrita. Por volta de 1800, com a eclosão romântica, na passagem de um mundo para outro, surgiu uma infinidade de diários, carnets de viagem, escritos auto-biográficos e memórias; em meados do século, a freqüência da escrita do diário tornou-se patente. Segundo um especialista, Alain Girard, foi então que o diário se tornou um novo gênero de escrita:

seu nascimento é o resultado de um encontro entre duas correntes dominantes que impregnam o pensamento e a sensibilidade da época: de um lado a exaltação do sentimento, $e$, na esteira de Rousseau, a moda, a onda das confissões; de outro, a ambição dos ideólogos ou homens alimentados pelo pensamento ideológico (como Benjamin Constant, Stendhal, Maine de Biran, Joubert...) de fundar uma "ciência do homem" baseada na observação, colocando na origem do entendimento a sensação (na linha de Locke, Helvetius e Condillac).

\footnotetext{
${ }^{1}$ Um diário feminino do mesmo período foi publicado como livro sob o nome de Minha vida de menina (1893-1895). São Paulo, Cia das Letras, 1998. Ver: FREITAS, Anamaria G. B. de e CunHA, M. Amália da. Dimensões da condição feminina no final do século XIX, nas páginas do Diário Minha vida de menina (1893-1895). Horizontes, vol. 19, Universidade de São Francisco, janeiro/ dezembro 2001, pp.29-42.
} 
Uma mulher e suas emoções

Esses pensadores queriam compreender as operações do espírito, as relações entre o físico e o moral, para melhor conhecer o homem. ${ }^{2}$

Foi então também que se criou nas jovens das elites o hábito de escrever o que é chamado em francês de journal intime, como parte de sua educação até o casamento. A instituição familiar encorajou o costume; a Igreja católica, porém, era mais cautelosa, temendo por meio dessa prática o desenvolvimento de características negativas, como o orgulho e a complacência para consigo mesma. ${ }^{3}$ A noção de "íntimo" é algo bastante indeterminado, sendo difícil defini-lo por meio de conteúdos. Para algo ser considerado como íntimo deve estar carregado de um alto grau de interioridade e não ser destinado à comunicação ou publicação imediatas; os conteúdos, nesse caso, podem variar ao infinito, sendo em razão da confidencialidade e não do conteúdo que taxaremos algo de íntimo. ${ }^{4}$

No final do século houve uma enxurrada de publicações póstumas, pois muitos escritores famosos escreveram diários que encontraram um enorme número de leitores interessados nos detalhes sobre suas vidas. Embora cada diário seja único, todos trazem um mesmo tipo de testemunho: a relação da experiência vivida, que se desenvolve e se aprofunda com o tempo. Há uma atitude comum diante da vida e do eu, diante de si mesmo. Os principais temas do pensamento contemporâneo - talvez até para nós lugares-comuns - se encontram esboçados nos escritos póstumos dos chamados "intimistas" do séc. XIX, e mesmo um leitor do século XXI pode nesses se reconhecer.

2 GIRARD, Alain. Le journal intime. Paris, PUF, $1^{\text {a }}$ ed. 1963, $2^{\text {a }}$ ed. 1986, pp.IX$\mathrm{X}$. Belíssima obra de mais de 600 páginas, com teoria e estudo de casos, enorme bibliografia, uma verdadeira bíblia para o tema.

3 Ver LEJEUnE, Philippe. Le moi des demoiselles: Enquête sur le journal de jeune fille. Paris, Seuil, 1993, pp.372-374; e GAY, Peter, A Educação dos Sentidos: Da rainha Victória a Freud. São Paulo, Cia. das Letras, 1988.

4 Baseamo-nos aqui em SALADO, R. et alii. La fiction de l'intime. Neuilly, Éditions Atlande, 2001, pp.17-18. 
Assim o diário tornou-se um "fato de civilização": é uma interrogação do indivíduo sobre sua nova posição no mundo, para reencontrar seu equilíbrio, típico de uma época de transição. ${ }^{5}$ Todas essas mudanças geraram um sentimento novo da pessoa, pois a noção de pessoa é diversa em tempos e/ou espaços diferentes. São os escritos na primeira pessoa - o "eu" - além dos diários, também as memórias e auto-biografias, que melhor testemunham essas transformações. Isso se deu numa temporalidade ampla que desembocou no individualismo ocidental contemporâneo.

$\mathrm{Na}$ segunda metade do século $\mathrm{XX}$, a memória $e$ a biografia floresceram mais ainda. O percurso da biografia - de aproximadamente dois milênios, numa perspectiva ampla oscilou entre as formas de conhecimento ou arte, ou seja, entre a "ciência" e a "arte", ou entre a história e a literatura. Em 1791, na Inglaterra, foi publicado Life of Samuel Johnson LL.D., de James Boswell, com imediato e enorme sucesso de vendas. Por sua preocupação nos novos métodos de investigar uma vida, por estabelecer uma relação forte de convivência biógrafo/biografado (com quase vinte anos de pesquisa e seis de narração), evitando o panegírico e o ideal de contar a verdade, com a dramatização de diálogos a partir de uma documentação sóbria, essa obra é considerada por muitos como um marco inicial do que hoje em dia é considerada uma boa biografia. ${ }^{6}$ Os analistas franceses

5 Outras obras interessantes são LEJEUNE, Philippe. Le pacte autobiographique. Paris, Seuil, 1975; GUNSDORF, George. La découverte de soi. Paris, PUF, 1948 e Lignes de vie :1- Les écritures du moi; 2- Auto-biographie. Paris, Odile Jacob, 1991. (Este é um debate com Philippe Lejeune, que mais tarde acabou em um processo feito por Lejeune contra Gunsdorf); LE RIDER, Jacques. Journaux de femmes. L'Impératrice Elisabeth, Marie Von Ebner-Eschenbach, Rosa Mayreder, Lou Andréas Salomé. In: LE RIDER, Jacques. Journaux Intimes Viennois. Paris, PUF/Perspectives Critiques, 2000; SIMONS, Judy. Diaries and Journals of Literary Women from Fanny Burney to Virginia Woolf. Londres, Macmillan, 1990.

${ }^{6}$ Para o conhecimento dos duzentos anos de percurso da biografia na Inglaterra, a partir do trabalho de Boswell, ver HoLmEs, Richard. Boswelll's Bicentenary. In: 
Uma mulher e suas emoções

apontam o surgimento do romance como a possibilidade de escrever a vida de um indivíduo, destacando sua extrema fragmentação, seus diversos tempos, o caráter contraditório e paradoxal dos pensamentos e das linguagens. ${ }^{7}$

Dois eixos claramente imbricados podem explicar hoje esse interesse pelas biografias e memórias: os movimentos da sociedade e o desenvolvimento das disciplinas que estudam o homem e sociedade. No primeiro eixo destaca-se um reforço enorme do individualismo, constatado por muitos dos autores: cada vez mais o indivíduo tem seu espaço na sociedade e cada vez mais o homem se detém nele mesmo. Também tem seu papel a discussão sobre a liberdade do indivíduo e sua relação com a sociedade, através das normas e valores, a partir das desilusões já muito discutidas da crise das utopias. Em relação ao segundo eixo - mudanças nas disciplinas - são fundamentais as já muito analisadas alterações nas formas de se escrever a história, derivadas das crises dos grandes paradigmas (marxismo e estruturalismo em particular). Assim, percebem-se reações contra conceitos totalizantes, como classe e mentalidades, contra categorias pré-determinadas (como revolução) e um favorecimento da experiência. O triunfo de um polimorfismo do homem (vindo da literatura e da psicanálise) teve também seu papel. $^{8}$

Atualmente a mídia entretém uma grande fome de imagens e testemunhos, uma enorme curiosidade sobre a dita "vida alheia": quer-se "consumir a vida dos outros", próximos e longínquos (e até mesmo imaginários, como nas novelas televisivas!). Alain de Botton ressalta:

Sidetracks: explorations of a romantic biographer. New York, Pantheon Books, 2000.

7 Ver LORIGA, Sabine. La biographie comme problème. In: REVEL, Jacques. (dir.) Jeu d'échelles: la micro-analyse à l'expérience. Paris, Seuil/Gallimard, 1996.

8 Ver BORGES, Vavy Pacheco. O historiador e seu personagem: algumas reflexões em torno da biografia. Horizontes, vol. 19, Universidade de São Francisco, Janeiro/Dezembro 2001, pp.1-10. 
Vavy Pacheco Borges

O voyeurismo das biografias tinha como pretexto a fama de seus sujeitos, quando, no fundo, o que existia poderia ter sido um desejo de bisbilhotar, de ver alguém em pleno ato de administrar o negócio da vida. ${ }^{9}$

O grande e recente boom da memória pode também ser entendido nessa linha, fundamentalmente ligada à perda de identidade causada pelas atuais massificação, midiatização e pela dita globalização.

$\mathrm{Na}$ França dos anos 1990, uma pesquisa sobre práticas culturais do Ministério da Cultura revelou que mais de três milhões de franceses mantinham alguma espécie de diário; muitos só por períodos, outros de forma mais contínua, com formas e funções diferentes. ${ }^{10}$ Um comentário recente da imprensa internacional informa que leitores estão devorando diários:

The appeal of journals is easy to understand/ a good one promises anedocte, confession, soul-searching and the odd revelation or whiff of scandal. Even the plain recording of every day facts allows the reader to enter directly into the writer`s mind and the world in which he leaves, and this, of course, can contain big surprises. ${ }^{11}$

Hoje em dia, com o progresso da técnica, faz sucesso na internet um novo tipo de diário, os "blogs", surgidos dentro de uma nova forma de sociabilidade, a do "chaf', mas que poderá também quem sabe - se tornar em outro novo "fato de civilização". ${ }^{12}$

Peter Gay, ao trabalhar alguns diários femininos do século XIX, lançou - através desses e outros tipos de fontes - "uma luz

9 De Botton, Alain. Nos mínimos detalhes. Rio de Janeiro, Rocco, 2000, p.18.

${ }^{10}$ Ver LEJEUNE, Philippe. (direc.) Le journal personnel. Paris, Université Paris X, 1993.

${ }^{11}$ Semanário inglês The Economist, 14-07-2001.

${ }^{12}$ Ver crônica de COELHO, Marcelo. Na internet, diários pessoais constroem a imagem da vida normal. Folha de S.Paulo, Caderno Ilustrada, 12-09-2001. 
Uma mulher e suas emoções

inesperada sobre a cultura burguesa" desse século, especialmente ao estudar sua sensibilidade $e$ sexualidade. ${ }^{13} \mathrm{Em}$ geral o historiador pensa o diário como um documento como os outros, passivel, portanto, de uma (antigamente chamada) "crítica interna", na qual é de muita valia o auxílio da psicanálise. Como diz o psicólogo Contardo Calligaris, por que achamos que o que vem num diário é em geral "A Verdade Factual"? ${ }^{14} \mathrm{O}$ diário é uma voz falando de si, que contém e lança uma imagem; o primeiro destinatário é sempre o próprio autor. Ao escrever um diário, o indivíduo desenvolve uma imagem de sua vida interior: do ponto de vista psicanalítico, o indivíduo quer se interpretar, confessar, justificar, pensar mais claro quando se vê em uma encruzilhada. O processo de escrita é, obviamente, sempre seletivo e ordenado.

Para Elisabeth Bruss, qualquer escrito sobre o "eu" pode ser visto como um "ato autobiográfico performativo", isto é, o sujeito (que fala ou escreve sobre si) "não é o objeto (re)presentado por seu discurso reflexivo, mas tampouco é o efeito, por assim dizer, gramatical de seu discurso. Falando e escrevendo, literalmente ele se produz". Assim, nem o sujeito é efeito do texto nem o texto é a representação do sujeito: o escrito autobiográfico é constitutivo do sujeito. Do conteúdo de um diário o indivíduo espera identidade, significação, valor: "Como cheguei a ser o que sou?" Podemos ver o diário, então, como o próprio sujeito se constituindo. ${ }^{15}$

\section{2- Eugénie Leuzinger Masset e seu diário}

Ela era o quinto rebento entre os dez filhos sobreviventes de Georges Leuzinger (suiço emigrado em 1832) e sua esposa francesa Eleonore Antoinette du Authier. Seu pai foi uma figura pública conhecida no mundo comercial e cultural da corte do

${ }^{13}$ GAY, Peter, A Educação dos Sentidos... Op. cit.

${ }^{14}$ Ver CALligaris, Contardo. Verdades de autobiografias e diários íntimos. Estudos Históricos n 21, "Arquivos Pessoais", pp.43-58.

${ }^{15}$ Bruss, Elisabeth. Autobiographical Acts: the Changing Situation of Literary Genre. Baltimore, John Hopkins University Press, 1976 apud Id., ib. 
Vavy Pacheco Borges

Segundo Reinado, como dono de papelaria e tipografia, editor, livreiro e fotógrafo. ${ }^{16}$

Como seus irmãos, Eugénie foi batizada protestante (religião de seu pai), mas durante sua vida foi uma fervorosa católica praticante (religião de sua mãe). Casou-se aos 23 anos com o francês - emigrado como seu pai e também como ele com loja na rua do Ouvidor - Gustave Léon Masset; ele viera de uma família francesa de Annecy, na Alta Savóia, para assumir uma loja de modas de outros Massets que andaram pelo Rio. Os negócios deram certo por um tempo, mas acabaram mal, assim como a saúde de Gustave. Eugénie ficou viúva aos 34 anos e com sete filhos para criar, dos 12 aos 2 anos. À procura de uma solução para a difícil situação financeira, que o casal já enfrentava antes da morte do marido, encontrou aquela adotada por algumas mulheres de seu grupo social quando precisavam de dinheiro: dedicou-se ao ensino privado. À frente do Colégio Masset, quatro anos depois de sua abertura ela registra no diário que o estabelecimento ia "bastante bem". ${ }^{17}$ No final da vida, orgulhava-

${ }^{16}$ Uma história do "velho comércio" no Rio, da autoria de Ernesto Senna, datada de 1908, traz talvez sua imagem mais antiga. SENNA, Ernesto. O velho commercio do Rio de Janeiro. Rio de Janeiro, Livraria Garnier Irmãos, 1908, pp.70 em diante. O brazilinista Laurence Hallewell, em sua história do livro no Brasil nos fornece também uma dimensão de sua atuação e contribuição na área. HAllewell, Laurence, O livro no Brasil (Sua história). São Paulo, T. ${ }^{a}$ Queirós/ EDUSP, 1985.

${ }^{17}$ Uma tia materna, a Baronesa de Geslin, ficara conhecida na corte por seu colégio. Num anúncio do Almanak Laemmert lê-se que lá eram educadas "com esmero as filhas das principais famílias do país". Intitulado "Collegio de Meninas", ficava na Rua do Príncipe do Cattete 25, "um dos lugares mais salubres do Rio de Janeiro (...) [no qual] ensina-se tudo que abrange uma educação completa tanto para a instrução geral e as artes do recreio, como para a moral e a religião". Alguns anos depois, num relatório sobre instrução primária e secundária na corte, em 1865, entre 37 estabelecimentos de ensino feminino encontra-se um "Colégio de Madame Leuzinger", no mesmo endereço. Eugénie tinha então 18 anos; suponho que possa ter sido um colégio então cuidado por sua mãe, na mesma casa onde a irmã desta mantivera o primeiro colégio. Talvez em 1880/1881 Eugénie tenha assumido o mesmo, hipotecando para tal sua casa 
Uma mulher e suas emoções

se de seu desempenho na tarefa do bom encaminhamento na vida profissional dos dois filhos homens e de ter casado bem todas suas cinco filhas e ainda, segundo ela, "sem dote"!

Seu diário foi redigido em um caderno de escrituração do escritório do pai, uma encadernação simples em couro cor de vinho, que traz dentro uma etiqueta com o nome G.Leuzinger \& Filhos, o endereço da "loja de papel e de objetos de escritório", na rua do Ouvidor, $31 e$ as datas das premiações nacionais $e$ internacionais ganhas pelos trabalhos da firma paterna. São cem folhas cobertas de uma caligrafia muito regular, precisa, bonita, homogênea e inalterada através dos dias e dos anos, com algumas exceções nos trechos finais ou quando fazia pequenos reparos posteriores apressados. Foi escrito à tinta, conta ela, com a caneta do marido "de ouro com ponta de diamante".

O diário é dedicado "à memória de meu querido esposo bem-amado Gustave Masset"; a dedicatória vem escrita em caligrafia de mão, desenhada em grandes caracteres. Escreve Eugénie: "minha força e minha coragem é você". Escrito em francês, traz poucos termos em português (como saudades, bambus, abraços). ${ }^{18} \mathrm{O}$ estilo é coloquial, muitas vezes pontuado só por vírgulas; bem redigido, revela a época, a educação $e$ a profissão de sua autora. Ela, porém, acha sua "linguagem dura e medíocre" $e$, lamentando ser "somente uma mulher, mas devotada e fiel", diz que gostaria de ser um "poeta para tornar seu nome adorado [do marido] imortal".

Eugénie escreveu regularmente de janeiro de 1885 até fevereiro de 1889; deixou de escrever justamente quando se completaram sete anos da morte do marido. Relia o que anotara em várias ocasiões posteriores (por exemplo, em 1907, 1908, 1918, 1914), fazendo novas reflexões em cima das páginas ou nos

própria casa da Rua Dona Mariana. No século XX algumas sobrinhas mantiveram um renomado "Colégio Masset". Minhas pesquisas ainda não elucidaram suficientemente esses e outros pormenores da vida de Eugénie.

${ }^{18}$ Os textos e frases do diário foram traduzidos do francês por mim e por meu marido Alain Jean Costilhes, bisneto de Eugénie. 
cantinhos onde sobrasse espaço; por vezes escrevia no alto da página a que ano aquelas recordações correspondiam. A última anotação parece ter sido feita em 1920, dois anos antes de sua morte, aos 75 anos. Escrevia sem regularidade, às vezes uma vez por mês, às vezes um período maior; em geral aos domingos à noite, quando provavelmente tinha um pouco mais de tempo e sossego. ${ }^{19}$ Suas lembranças são despertadas pelas aflições e angústia advindas da saudade, solidão, melancolia, provavelmente por todos esses sentimentos misturados. Por vezes, as datas significativas de sua vida amorosa (morte dele, aniversário dela ou dele, data de casamento) parecem suscitar ou comandar as recordações.

A evolução dos anos faz com que ela, ao reler, veja muitos de seus registros de forma diversa. Por exemplo: num dos textos que intitulou "Pensamentos que atravessam meu coração e meu espírito", em 1920 escreveu em cima a lápis: "Sonhos"; sobre outros trechos de lembranças: "Ilusões de amor" ou "Adeus aos sonhos". Exerceu uma censura forte em uma ou duas folhas cortadas sobre sua noite de núpcias (justamente sobre o momento da consumação do casamento) e em mais duas páginas no final do diário (sem deixar pistas dos motivos que a levaram à censura). Sua raiva e revolta contra Deus também são censuradas; mais de uma vez o diário revela que na hora da morte do amado se revoltou contra Deus; depois rasura por cima:

Ah! Deus nos tinha retirado tudo, posição, fortuna, bemestar, saúde, e eu sempre o abençoara, mas quando me

\footnotetext{
${ }^{19}$ As mulheres donas-de-casa e mães, por suas atividades diurnas, em geral, aproveitam esses horários noturnos para seus prazeres pessoais. Outro caso de diário desse tipo é o de Madame Lamartine, mãe do poeta francês. Diz ele: "Minha mãe tinha o hábito (...) de fazer um intervalo entre o dia e o sono (...) Quando todo mundo estava deitado na casa, quando seus filhos dormiam em suas caminhas perto da sua (...). Ela escrevia algumas notas jogadas no papel, final dos dias, como gotas de sua existência (...) um tesouro precioso de lembranças para seus filhos". LeJEUNE, P. Le moi des demoiselles... Op.cit., pp.354-355
} 
Uma mulher e suas emoções

levou meu bem-amado, meu amor, minha própria alma... [E por cima, entre parênteses] Cala a boca? Silêncio... Deus sabe o que faz, que Ele me perdoe [Mas diz que, mesmo assim, Deus] com sua mão caridosa, tratou de sua ferida. [Por dois longos meses sofreu] uma agonia terrível, um pesadelo fulminante... [teve] o desespero na alma $e$ esqueceu tudo, Deus e suas crianças, ao receber seu último suspiro...

Mas pediu perdão a Deus e filhos e disse que o resto de sua vida lhes pertenceria. Quando confessou ao padre sua revolta, sentiu-se aliviada e concluiu dizendo que esse foi "um bom dia".

Entre suas lembranças, copia três cartas que enviara para suas irmãs Léonie e Mathilde. O final do diário é confuso, entrecortado, fragmentado, descosido. Copia poemas (a maioria em francês, mas alguns em português, de Vitor Hugo, Miguel de Barros, ou de sua própria autoria), curtos pensamentos e orações. A impressão que dá é que as orações vêm sobretudo depois, como por exemplo em 1920, quando ela copia na contracapa inicial uma de seu próprio punho. Bem mais tarde Eugénie registra agradecimentos a Deus por ter-lhe conservado todos seus filhos; quando o último se casa, anota que Deus lhe concedeu a graça de terminar sua tarefa.

No final de sua vida, com uma letra realmente alterada, escreve essas linhas, quase seu epitáfio:

Infelizmente a vida é triste! E muda com o Tempo, os corações, as afeições, as alegrias e as tristezas. Sobram somente a amargura, a indiferença ou uma dor silenciosa $e$ surda que nos leva docemente ao túmulo. Isto é a vida! $\mathrm{E}$ ninguém sai dela com um sorriso nos lábios! Mas se temos a paz na alma, a graça de Deus nos guiará, e esse último sorriso misterioso do coração é tão doce... [Mas ela mesma registra] Meu epitáfio desejado: Viva em paz, no seio de teu Criador, ao lado de seu esposo. Você que passa, reze por eles! 
Vavy Pacheco Borges

Em uma das contracapas, deixou uma síntese de seu diário e/ou de sua vida:

Primeiras lembranças. 1881-1887

Eclosão do amor sobre a terra. 20 anos

Submissão à vontade de meu Deus. 30 anos

Aspiração ao amor de Jesus-Deus Todo-poderoso. 68 a 73

anos.

\section{3- O diário: sintoma/remédio - e prazer}

A psicanalista Sophie de Mijolla-Mellor analisa certa forma de diário como algo que pode ajudar a viver, que denomina "diário sintoma, diário remédio", pois expressa algo e procura curar esse sintoma. Para a psicanálise, acrescenta, todo sintoma é já em si uma forma de remédio:

Sinal de um conflito, de uma impossibilidade de se dar satisfação a uma exigência pulsional, que ameaçaria o equilibrio do eu, o sintoma fornece, sob a forma inversa do sofrimento um substituto, um meio termo, uma espécie de arranjo entre o desejo e a defensiva. Se, portanto, quer-se considerar o diário como um sintoma, isso compreende que ele seja um remédio contra a desorganização psíquica. Há, assim, uma parte ligada ao sofrimento e ao seu alívio, ou, ao menos, à sua expressão. ${ }^{20}$

Na procura de enfrentar sua viuvez prematura, aos 34 anos, quando ainda desejava viver sua relação muito apaixonada, o diário de Eugénie parece ter tido exatamente esse papel. As primeiras linhas dizem:

(...) começo este caderno para aqui reunir todas as lembranças esparsas que momentos de felicidade ou de

${ }^{20}$ LEJEUNE, P. Le journal personnel. Op.cit., pp.71-75. 
Uma mulher e suas emoções

angústia arrancaram de meu coração, de meu pensamento, de minha pena.

Durante os primeiros anos em que escreveu, o diário parece ser, ao mesmo tempo, um sintoma de sua solidão e uma forma de tentar acalmá-la, sentindo novamente alguma forma de prazer em seu passado com Gustave. Inúmeros exemplos mostram que a finalidade é uma procura de alívio para sua dor. Afirma no segundo ano do diário: "Resta-me somente a lembrança, é esse o tesouro que me sustenta e consola". Creio que é quando já consegue trabalhar com a perda do marido que começa a escrever, em 19 de janeiro de 1885 (data do aniversário de noivado):

Dando vazão a tudo que transborda de um coração fechado três anos e quatro meses, eu procuro um alívio para meu mal moral. A alma ferida se alimenta de suas próprias lágrimas (...) É para me consolar, para poder conversar e elevar meu pensamento até meu querido ausente que eu me decidi a escrever (...) [para lembrar] nossos raros momentos de lazer (...) que são os que me permitem viver para mim mesma este presente (...) [mas] somente consigo captar uma sombra doce e melancólica... [E depois, bem mais tarde, acrescentou em baixo em português] Uma inconsolável.

Eugénie percebe a ambigüidade desse mergulho no passado à procura de bons momentos vividos:

eu saio arrasada, minha dor os saboreia e minha razão os recusa. [Em outro momento escreve] Ah, em meus momentos de angústia, muitas vezes, pensei que no caminho penoso que me resta fazer eu deveria reunir todas minhas forças para tornar-me insensível!

Em 1920, escreve na $1^{a}$ contracapa do diário: "meu grande consolo moral foi sempre escrever minha vida, meus pensamentos 
$e$ as belas orações e sentenças que amo, que admiro, que desejo imitar para a graça de meu Deus Todopoderoso"; e grifa: E.L.M. Estas frases mostram o que pode ser considerado como uma outra, uma segunda parte do diário, que deu seqüência aos relatos biográficos até 1889 , fundamento e razão do diário. O que marca e estrutura o diário, o que constitui sua matéria prima básica são as descrições dos sentimentos de Eugénie. Ela fornece algumas pistas sobre ela mesma: "o perigo me atrai mais do que me assusta"; "fazia parte de meu caráter ir direto ao obstáculo e o atacar de frente". E mostra seu amadurecimento de donzela de elite, poupada na juventude, ao escrever:

\begin{abstract}
A vida não se transforma de acordo com um capricho. Nela tudo é grave e sério. Eu logo compreendi isso. [Redige ou copia frases sobre a persistência na vida] ...para conseguir é preciso querer; em um ser que tem vontade, tudo o que é uma constatação de sua própria força moral lhe causa uma secreta sensação secreta de poder. ${ }^{21}$
\end{abstract}

Suas descrições de ambientes e situações da vida com Gustave são tão vivas que diversos trechos parecem um romance ou um filme. Eugénie narra de forma bonita e delicada o início de seu amor pelo marido, as relações entre os dois desde o primeiro olhar, sorriso ou beijo, até o último. Reproduz, por vezes, o cotidiano da vida a dois e da vida familiar de forma belíssima $e$ singela. É preciso buscar cuidadosamente os dados informativos em meio a enxurrada subjetiva de sentimentos e emoções que descreve: o início de seu romance, o pedido de casamento, o noivado na casa paterna da rua da Princesa, no Catete, o casamento na igreja do Outeiro da Glória em 11 de julho de 1868, as casas onde o casal morou - a primeira, na rua do Ouvidor

${ }^{21} \mathrm{O}$ conteúdo do diário permitiria um mergulho muito profundo em sua alma. Não pretendemos aqui qualquer tentativa de explicação psicológica ou busca de uma "identidade" de Eugénie, somente uma exploração inicial de caráter histórico de seu diário. 
Uma mulher e suas emoções

esquina com rua Nova do Ouvidor, em cima da loja do marido ${ }^{22}$; depois, a que ele construiu para ela quando já tinham quatro filhos, na rua Dona Mariana em Botafogo, hipotecada na longa enfermidade sem dinheiro de Gustave; a morte de Gustave no Hotel da Vista Alegre em Santa Tereza (local de refúgio num Rio ainda insalubre), o apoio e carinho de seus pais à viúva e aos sete netos órfãos.

Entre tanta paixão a reviver, pouco espaço é ocupado pela infância, adolescência e vida de solteira de Eugénie. Diz ter sido tímida e sensível; vê-se como a "companheira fiel" de seu pai. Afirma que sofreu muito, aos 9 anos e meio, com sua entrada no colégio interno e conseqüente separação dos pais até 13 anos e meio, quando voltou à casa para freqüentar um pensionato. ${ }^{23}$ Ela confessa um grande amor pela música e pelas ciências. Conta que aos 15 anos estava feliz em viver; aos 18 se sente ainda contente da vida, mas já mais preocupada. Diz que poderia ter continuado seus estudos, mas o casamento a impediu. ${ }^{24}$

Obviamente conversando consigo mesma, seu ato de escrever, nos primeiros anos, pretendia ser uma longa e recorrente conversa com o marido falecido. Os exemplos seriam inúmeros, entre o quais: "Veja meu querido, meu consolo é conversar com você, você está longe, bem longe, mas no meu coração você está perto de mim, esse é seu santuário". Creio que um bom exemplo são as primeiras vinte páginas:

${ }^{22}$ A rua do Ouvidor não deveria ser um lugar para se criar uma família, sendo como disse Machado de Assis a "cara do Rio", centro de novidades e boatos e o famoso centro de compras que ele chamou de "via dolorosa dos maridos pobres".

${ }^{23}$ Segundo outras fontes, ela e sua irmã Sabine estudaram no Colégio Hutchings; teve aulas de desenho com o professor Viardet, como mostram desenhos num álbum de fotos e lembranças que foi seu, e hoje é parte do acervo do Instituto Moreira Salles de São Paulo, por mim identificado como tendo sido de Eugénie.

${ }^{24}$ Um quadro geral da educação feminina de elite me foi fornecido por BRICARD, Isabelle. Saintes ou Pouliches: I'éducation des jeunes filles au XIX'éme siècle, Paris, Albin Michel, 1985; e DuBY, G. et PERROT, M. Histoire des femmes. Vol. 4 - Le XIX ème siècle -, Paris, Plon, 1991. 
Vavy Pacheco Borges

Vamos conversar, você quer? Nós estamos em nossa bonita casinha na rua Da Mariana, 11, as crianças dormem, a casa está silenciosa, estamos os dois sozinhos embaixo na salinha, as persianas bem fechadas, com uma luz doce que inspira uma prosa íntima. Eu trabalho, você lê "La Revue des Deux Mondes", sempre livros sérios, e fuma seu cachimbo feio (...) Eu, então, largo o que faço, um vestidinho ou camisinha, me levanto, arranco bruscamente seu livro, rasgando um pedacinho da página que sobra entre seus dedos, é um pedacinho de nada, mas você reclama "A revista!", quer se zangar, mas eu envio um beijo com um sorriso e sua grossa voz se suaviza e diz: "Ora, criança, passe-me meu livro!" Eu, orgulhosa de minha primeira vitória arranco seu cachimbo, você quer então realmente se zangar mas eu calo você com um beijo e me sento no seu colo. Você então me cobre de carícias e diz: "Agora está contente, não é, Coquete? Me dá meu livro já, mas nunca são horas de ler, primeiro tive que brincar com as crianças, agora é com a criança grande". Eu faço cara de aborrecida, quero sair da sala. Não sei o que você vê na minha cara, talvez um momento delicioso que se perdeu; então você me segura, eu me instalo mais comodamente sobre seus joelhos, passo os dois braços em volta de seu pescoço abraçando essa cabeça tão amada e depois folheamos juntos o livro mais lindo do mundo, o livro do coração e do pensamento, do amor enfim, em tudo que há de mais belo, de mais puro, de mais sagrado; você esquadrinha todos os recantos de um coração que é todo seu (...) E você, sempre bom e amoroso, diz que sempre descobre em meu coração caminhos novos e cada vez mais brilhantes - adulador! - você conhece bastante bem seu poder sobre esse coração onde fez nascer uma flor tão linda, a "paixão", mas paixão com tudo que essa tem de mais puro e de mais louco. Mas falemos de outras coisas, continuemos nossa conversa, ela me faz bem. (...) Chega por hoje, meu amado, o dever me chama para esta terra, eu saio de seu colo, deposito sobre sua boca um daqueles 
Uma mulher e suas emoções

beijos longos que fazem minha alma passar para a sua; sonhar com você é minha única felicidade, mas acordar é tão cruel!

Mas há também outro interlocutor, outra presença forte no diário, que permanece nos anos finais em que Eugénie só relê suas lembranças e acrescenta frases ou orações: o Deus dessa católica fervorosa. Ela escreve para o marido sobre seu amor por Deus:

Você sabe bem que eu sentia esse amor tão poderoso, eu temia que Deus ficasse ciumento e, mais de uma vez, eu Lhe supliquei que me retirasse todos meus outros bens desta terra exceto você, meu único amor, e nossos sete filhos, nossa própria carne.

Mas na maior parte do tempo, os dois - marido desaparecido e Deus - parecem se misturar como se fossem um único amor, pois os dois eram, segundo repete várias vezes, seu consolo e sua força. ${ }^{25}$

Desde o início de minha leitura me parecia que ela os superpunha, pois as duas figuras apareciam por vezes como uma só. Bem mais adiante, leio surpresa que ela mesma tinha consciência dessa confusão e disso se acusou para seu padre confessor, na $5^{\text {a }}$ feira da Semana Santa de 1886. Reflete:

Por que não se ama a confissão? Ela é sublime, indispensável para um penitente. [E relata a sua confissão] Meu pai, será que é um pecado pensar em Deus quando penso em meu marido que perdi faz quatro anos e meio, será que é uma falta pensar em meu marido cada vez que rezo a Deus, quando peço sua proteção para mim, para meus filhos? Eu os confundo em meus pensamentos $e$ minhas orações, eu me sinto atraída pelo céu desde que ele

${ }^{25}$ Nos conventos femininos as religiosas são consideradas as "esposas do Senhor" ou "esposas de Cristo". 
Vavy Pacheco Borges

se foi, eu rezo para mim e meus filhos e entretanto rezo a

Deus por ele também.

Acrescenta que o padre era não somente bom mas instruído, inteligente e inspirado por Deus; não a condenou, afirmando que foi Deus quem tudo criou, o que é bom; eliminando qualquer noção de culpa, a encorajou a rezar e sofrer com paciência para educar as crianças. ${ }^{26}$ Eugénie parece bem aliviada em ter falado ao padre confessor, pois termina aquele relato afirmando que esse (outra vez) foi um "bom dia".

\section{4- A imagem que o diário revela}

${ }^{26}$ Podemos ver algo semelhante, que deveria ser comum entre as católicas praticantes da época, numa prece em francês encontrada entre os pertences de Virginia Cândida Ribeiro Ferreira da Rosa (1898-1993, sogra de minha irmã Cecília), por ocasião de seu falecimento em São Paulo: "Prece de uma mulher Cristã: Senhor, fostes vós que me deste, no esposo que me houveste unido, um guia para minha inexperiência, um protetor para a minha fragilidade, um amigo fiel para os bons e maus dias, na alegria e na tristeza. Foste vós, meu Deus, que criastes os laços que me unem a ele, eles são o fruto de vossa suprema sabedoria, todavia eu não devo me esquecer que vós sois chamado nas Escrituras de 'Deus ciumento' e que vós quereis ser o primeiro objeto de meu amor. Concedei-me, portanto. de que eu fielmente guarde para vós o primeiro lugar no meu coração, o qual vos pertence fora de dúvidas; mas fazei que, após o Senhor, após a felicidade de poder servi-lo, eu possa unir-me ao meu marido, com o objetivo de fazê-lo feliz, de me ocupar inteiramente dele. Fazei com que através da minha manifesta ternura e devoção, de meu humor sempre igual, a abnegação de minha vontade, eu atenda a seus mínimos desejos, eu torne sua vida agradável e suave, e que ele encontre em seu lar um ambiente infinitamente melhor que qualquer diversão em outro local. Dê a minha alma, meu Deus, as virtudes domésticas que formam a imortal beleza de uma mulher cristã aos olhos de seu esposo, e que o tempo não as apague tal como vantagens efêmeras e frágeis. Possamos nós, Senhor, apoiarmos-nos um ao outro e sagradamente unidos, atravessarmos juntos com devoção os dias de nossa vida mortal, nos dedicarmos mutuamente a vosso serviço, e trabalharmos para a vossa glória e a nossa salvação. Possamos nós dois juntos, ao pé de vosso altar, não sermos destruídos pela morte, e permanecermos inseparáveis no céu, da mesma maneira que na terra. Assim seja". 
Uma mulher e suas emoções

A primeira caraterística de Eugénie que se percebe é a de uma mulher apaixonadíssima. Ela lembra o início do romance:

O amor que você me inspirou veio pouco a pouco; mas tomou de tal forma meu ser todo inteiro que eu percorri todas as fases do amor e creio que depois de 13 anos eu amava você mais do que no primeiro ano de nossa união. Se é que posso chamar de mais o que era já apaixonado, violento, ciumento, louco, doce, terno, confiante, puro, o céu, enfim!

Sua paixão é patente desde a forma com que descreve os detalhes da sua vida com o marido: "Minha felicidade durou 13 anos, 2 meses e 6 dias", pois ficou viúva em " 17 de setembro de 1881, às 8 horas menos 13 minutos". Enérgica e decidida em seus atos, revela-se no diário romântica e idealizadora: "Minha convicção é que para que os esposos sejam felizes, antes da consumação do ato do casamento, antes que seus corpos se unam, as almas devem se confundir". Talvez não difira aí do romantismo de muitas jovens de sua época, entendendo-se aqui o termo no senso-comum mais moderno do século vinte.

O temperamento apaixonado se evidencia também quando ela se confessa por mais de uma vez muito ciumenta seja dos amigos de infância de Gustave (que, segundo ela, os defendia com eloquência e paixão), seja da família dele, pois praticamente não se refere a ela. ${ }^{27}$ Descreve o dia de seu casamento, sua roupa, o cortejo, a cerimônia, os cumprimentos, o jantar, os toasts, durante os quais se sentiu incomodada ao ser tão observada. Conta sobre sua noite de núpcias (com "as novas necessidades do casamento", que a deixaram "feliz de lhe pertencer, enfim" e "ele tomara posse não só de meu corpo, mas de minha alma, todo meu ser"), sobre a manhã seguinte, a semana de lua de mel em

${ }^{27}$ A família de Gustave morava na França. Por outras fontes se sabe que Eugénie esteve pelo menos uma vez na Europa com ele, visitando-os, mas ela não menciona tal fato; creio que não deveria gostar de recordá-lo. 
Petrópolis, com passeios a cavalo e de carro, a visita dos pais, tudo entremeado com comentários sobre seus sentimentos, suas reserva e timidez, suas fortes emoções: "Os recém-casados amam a solidão $e$ em especial $e u$, que sou selvagem $e$ naturalmente ciumenta, queria cercar de mistério minha felicidade no hotel inglês Mack Donal" (em Petrópolis). Diz estar persuadida de que a felicidade conjugal se resolve "nos primeiros 8 dias".

Ao voltar ao Rio para iniciar sua nova vida, pensou:

Ah, um mundo separa a donzela da jovem recém-casada $e$ esta fica orgulhosamente intimidada com o caminho percorrido! De volta à cidade (do Rio de Janeiro) fiquei presa na engrenagem dessa grande roda que chamam de vida e entrei nela com uma fé viva, uma confiança cega $e$ uma esperança brilhante e sorridente, parecia-me que o braço sobre o qual me apoiava me levaria a um bom porto e meu pressentimento não me enganava. [E acrescenta, fortemente pesarosa] Ele foi durante treze anos e dois meses minha felicidade e minha alegria e hoje que está longe, bem longe, brilha ainda em meu coração como uma estrela consoladora e benfeitora, ele é minha força, e minha finalidade, a força de coragem, paciência e resignação.

Ao relembrar a chegada à sua primeira casa descreve:

Eu aí entrei como uma rainhazinha nesses domínios (...) Seu pequeno apartamento encantador, simples, alegre, de bom gosto, fez-me tremer de alegria e de amor (...) O primeiro andar era ocupado pelos escritórios de meu marido, os aposentos dos empregados, a cozinha e a sala de jantar. [Lembra os olhares, sorrisos e contactos entre os dois e continua] Eu me sentia alegre como um passarinho $e$ leve como uma borboleta, ia e vinha nesse salão onde me sentia dona e rainha. [A impressão do quarto para ela é ainda melhor] com alguma coisa mais de íntimo e mais inebriante (...) $\mathrm{Em}$ mim as grandes emoções sempre se 
Uma mulher e suas emoções

traduzem sobretudo nos meus olhos, no meu olhar, nos meus lábios trêmulos.

O sexo parece ser um componente importante da paixão de Eugénie; está subjacente em várias partes, pouco explicitado ou censurado (talvez temendo possíveis leitores). Sua forma de cortar a consumação da noite de núpcias é reveladora, assim como o relato da concepção de seu caçula, que descreve delicadamente através da metáfora de um beijo:

Essa criança nascida depois de uma noite de baile e de loucura e que brotou entre nossos lábios no momento em que os últimos véus da noite lutavam contra os primeiros raios do dia $!^{28}$ Esta criança nascida do beijo o mais cheio de loucura, o mais radioso, o mais terno, o mais louco, o mais desesperado! $!^{29}$

Diz que foi feliz por ter pertencido a ele "de corpo e alma". Mais de uma vez demonstra sua felicidade por sonhar com os dois juntos se abraçando e se beijando, em agrados que lhe causavam "êxtase"; agradece a Deus por poder ainda ter esse prazer com o marido. Escreve que ele, ao voltar de viagem à Europa lhe dissera:

Existem em você duas mulheres, uma doce mas um pouco fria e uma outra a amante sempre renovada que me faz percorrer os caminhos encantadores e novos de um coração que acredito conhecer (...) [E mais] Você é a mais deliciosa das amantes.

${ }^{28} \mathrm{O}$ baile, anota depois, foi no palacete do irmão Edmond, no Largo dos Leões, onde também moravam seus pais.

${ }^{29}$ Peter Gay menciona, em seu já citado estudo casos semelhantes, que "Por razões bastante óbvias as relações sexuais, sendo experiências das mais íntimas e mais importantes de todas as experiências, também são das menos documentadas". GAY, Peter, A Educação dos Sentidos... Op. cit., Item I Experiências Burguesas: um registro erótico -, p.61. 
O diário indica que ela viveu sem muitas tensões a dicotomia alma e corpo (antiga discussão na filosofia e na religião), que atormentou por muitos tempos as católicas praticantes. Quando menciona algo do amor como "louco", talvez esteja se referindo ao sexo, por vezes, em contraste com o "puro" (que seriam os sentimentos românticos). Para Peter Gay, em muitos casos ficou documentado que "o amor era fundamental $e$ indispensável para essas mulheres, constituindo o fundamento, a coroação e a razão de ser da sexualidade ${ }^{30}$ Eugénie parece ter vivido bem o papel de esposa/amante pela sua enorme paixão por Gustave Masset.

A doença dele e seus problemas financeiros já prenunciavam o fim de sua vida comum amorosa. Em determinado momento escreve:

Ah! Nesta época ele tinha muitas preocupações, seus negócios iam mal, seu moral sofria e o físico pagava seu tributo, e ainda mais, ele nos amava muito, o pobre querido, $e$ o pensamento que não podia nos garantir o mesmo bem-estar o torturava (...) E foi a casa da rua Mariana número 11, com seus cômodos cheios de lembranças do nascimento de nossos três últimos filhos, cômodos cheios de conversas lamentáveis ou alegres, apaixonadas ou calmas e doces, foi essa casa onde cada canto, cada cômodo, cada pedra olha para nós como amigos, que nós tivemos que abandonar, $e$ isso seria para sempre, algo que adivinhamos em nosso sofrimento cruel. [Mais tarde escreve a lápis] Ele tinha perdido toda sua fortuna e o desespero é que o derrubou... [concluindo] $\mathrm{Eu}$ tinha saúde e resisti, ele não, sucumbiu.

\footnotetext{
${ }^{30}$ Peter Gay, em seu ensaio, afirma que muitas "Autobiografias e diários íntimos oferecem-nos ricas e convincentes provas de que houve, no século burguês, casamentos bem sucedidos e que elevaram os prazeres sensuais compartilhados à condição de elemento indispensável". GAY, Peter. A educação dos sentidos... Op. cit., capítulo "Doces comunhões burguesas", p.109.
} 
Uma mulher e suas emoções

Sua paixão se evidencia, ainda, não pelas formas de seu luto - representativas de seu grupo social e época - mas pelos sentimentos que o acompanharam. $\mathrm{O}$ primeiro aniversário da morte dele foi comemorado com os oito de preto, reunidos em volta do túmulo. Conta que não parava de chorar, não conseguia sair de lá até que os filhos disessem: "mamãezinha, vamos embora que já é tarde". Iam repetidas vezes ao cemitério rezar e depositar flores e nos aniversários de morte, além dessa cerimônia, as crianças a beijavam especialmente e enchiam de flores as fotos que tinham em cada quarto. Relata que chega a disputar com os filhos quem dava o último beijo no túmulo, mas "o olhar espantado deles me fazia cair em mim mesma". Usava o tempo todo um medalhão com a imagem de Gustave, que chamava de seu talismã;

[faz com que] todas as manhãs e noites, as crianças abracem você em pensamento, como abraçam sua pobre mãe, eles falam de seu pai bem-amado, lembram-se de você, depositando sobre o medalhão, santa relíquia, um beijo e um pedido de benção. [Escreve em outra ocasião] $\mathrm{O}$ silêncio que se faz em torno dele me aperta o coração. Meus filhos falam pouco dele, com medo de "entristecêla"... [Diz-se] angustiada [pois] eles me olham ansiosos, procurando ler em minha alma (...)

O amor aos filhos, aos quais dedicou seu tempo e todos seus esforços, tem uma presença muitíssimo menor no diário do que a paixão pelo marido. "Conversa" com o marido: "Eu sou ruim, eu te amo mais que a nossos filhos". Em certo momento, ao falar sobre os inúmeros filhos, deixa escapar de leve que o casal não gostaria de ter tido tantos, mas que era importante considerálos uma "benção de Deus". Chama os filhos de "as sete provas de seu amor por mim", "nossa própria carne"; chama-os também de seus "anjos da guarda". Constituem fundamentalmente a tarefa na vida que lhe resta: em 1885, conta que o colégio ia muito bem, 
se tenho muitos alunos estou contente, pois é o pão de meus filhos que ganho, vejo-os contentes, posso proporcionar-lhes pequenos prazeres e posso, sobretudo, aumentar seus conhecimentos intelectuais, posso eu mesma formar-lhes o coração, guiá-los na virtude.

Diz querer criar o coração e espírito dos filhos à imagem do pai. Pede a Deus saúde, tempo e coragem para educá-los, pois tem uma "carga dupla para com os filhos que não mais têm um pai e para com as crianças que me são confiadas". Assim, engloba sua missão de mãe e educadora numa tarefa única, sendo um exemplo da "mãe-professora se transformando na professoramãe", nessa passagem de uma esfera para outra da vida social. ${ }^{31}$

Os filhos não são citados nominalmente, em geral, as referências são ao conjunto, exceção feita ao caçula - "meu pequeno Georginho", cujo nome é o mesmo de seu pai. É esse que Eugénie identifica mais com seu marido:

aquele que até hoje parece ser um laço entre minha alma $e$ a de seu pai bem-amado (...) Essa criança que, brotando entre nossos lábios, unia nossas duas almas e parecia dizer "Não nos abandone".

No final de sua vida, deixa registrado que foi esse o filho que sempre a amou, consolou e protegeu.

Outra característica marcante da imagem que ressalta do diário é de uma mulher cujo papel social se cindiu com a doença e perda do marido "senhor e mestre", como ela o qualificou em um trecho. Muitas falas me levaram a vê-la dividida entre os dois tipos de mulher: a mulher tradicional, que viveu como esposa-mãe e dona-de-casa por 13 anos e lhe dava o maior prazer, e a função que depois foi obrigada pelas circunstâncias a desenvolver na vida pública e profissional.

${ }^{31}$ Fraise, G. et Perrot, M. Ordres et libertés. In: Duby, G. et PeRrot, M. Histoire des femmes. Op. cit., pp.15-16. 
Uma mulher e suas emoções

Ela passa uma imagem felicíssima em seu primeiro papel. Em suas palavras, o dia 11 julho de 1868, dia do seu casamento, "fez de uma virgem pura e cristã uma mulher santa e fiel, uma esposa e uma mãe". Uma belíssima descrição da realidade cotidiana da família é muito reveladora:

Eu ainda me vejo lá, nesse salãozinho, costurando uma roupinha enquanto meu bebê caçula, habituado ao barulho dos irmãozinhos, dorme tranqüilamente, num carrinho ao meu lado. Um pouco mais longe, dois de seus irmãos, sentados no chão ou correndo de cá para lá, bagunçavam todos os brinquedos que retiram de um armário que era só deles, divido em 6 repartições e que eles orgulhosamente chamavam de "nossa casa". De vez em quando, uma briga entre eles me fazia ter que intervir a favor de um ou de outro. No salão ao lado, minha filha mais velha, com 11 anos, estudava piano, enquanto as outras duas e meu filho mais velho, de 6 anos, faziam suas lições sobre a mesa da sala de jantar, diante de uma porta aberta que dava para meu salãozinho. Depois eu abandonava meu trabalho de mão, dava de mamar ao bebê, abraçava-o apaixonadamente, ele era tão lindo, tão fresco, tão rechonchudo, tão alegre; a empregada estendia no chão uma toalha, onde eu o colocava, olhando com paixão seus movimentos desajeitados, mas, entretanto, tão graciosos; as duas irmãzinhas corriam para trazer-lhe brinquedos e riam às gargalhadas dos esforços que o irmãozinho fazia para pegar um brinquedo que escapava de seus dedinhos tão desajeitados e que, no entanto, dava vontade de comer de beijos. Eu abraçava os três novamente, recomendando-lhes de serem bonzinhos $e$ obedecerem à empregada $e$ entrava na sala de jantar onde os quatro mais velhos estavam prontinhos para a aula. Eu lhes ensinava francês, português, piano e um pouco de geografia. Terminada a aula, meus prisioneirozinhos se mandavam, o sol não queimava mais tanto, as minhas grandes árvores davam uma boa sombra e meus sete passarinhos cantavam e riam, se compensando largamente com algumas horas de 
Vavy Pacheco Borges

tranqüilidade. Eu os deixava sob os cuidados de uma empregada, mas, assim mesmo, pelas janelas que rodeavam minha casa, estava sempre vigiando. Antes de subir para trocar de roupa e passar um vestido para receber meu senhor e mestre, eu dava uma volta pela cozinha e pela lavanderia e subia para meu quarto de vestir onde passava meu vestido e descia, retomando meu trabalho de mão seja no salãozinho seja no jardim, esperando a chegada de meu marido. E quando escutávamos de longe o bonde se aproximar e parar, as crianças corriam para a grade, meu coração se alegrava e após algumas pequenas desilusões nós o víamos finalmente chegar. Seu primeiro "boa noite" era um sorriso geral que nos abraçava a todos, depois as crianças se jogavam nas suas pernas, disputando o primeiro beijo, eu lhe passava o bebê por cima da cabeça dos outros seis, seu filho caçula que tinha apenas alguns meses, ele o abraçava, portanto, primeiro, para grande desgosto dos outros que o forçavam a se abaixar e os beijar um por um, depois era a minha vez, em último, eu dizia-lhe rindo que só cedia minha vez porque era para os filhos, isso o fazia rir e me rendia um beijo a mais. As crianças o desembaraçavam de seu pacote ou bengala, ele pegava em seus braços o caçula, eu me apoiava sobre seu ombro $e$ entrávamos lentamente em nossa sala de jantar. Infelizmente aí sua cara já estava séria e em duas palavras ele me explicava uma nova preocupação, ou fazia um gesto de sofrimento.

Eugénie aparece ainda como tradicional e romântica ao escrever uma carta para a irmã Matilde que, ficando viúva, casouse de novo: "É tão bom ser amada e protegida por um ser mais forte". Para o novo cunhado, manda um recado:

Diga-lhe de minha parte que é muito bom ter uma mulherzinha submissa e sempre alegre, mas também é bom ter um marido louco pela mulher, que seja criança de vez em quando, embora firme e sempre afetuoso. Veja você, não há pessoa alguma no mundo, nem pai, nem mãe, nem 
Uma mulher e suas emoções

irmão, nem irmã, nem amiga nem filho que possa substituir o amor entre dois esposos. [Afirma que uma mulher sozinha na vida se sente] um zero e gostaria de se apoiar na proteção de um homem de honra e de coração.

Ela foi uma daquelas mulheres que ajudou a abalar as estruturas dos antigos papéis femininos; as circunstâncias a empurraram e ela não teve qualquer intenção de ser o que definiríamos como feminista. Muito forte, com excepcional experiência de vida, teve que lutar no campo profissional, tornando-se assim uma "nova mulher". ${ }^{32}$

Em capítulo intitulado "Minha vida pública, minha vida de trabalho" mostra sua dificuldade de sair da segurança da vida privada para o risco e a exposição da vida pública:

Assim que vi que meu nome estava exposto a todos os olhares [refere-se ao nome do Colégio Masset] em letras grandes, em uma placa suspensa acima de minha porta, enquanto que eu deveria enfrentar em minha casa a presença dos primeiros candidatos, homem ou mulher, jovem ou velho, rico ou pobre, delicado ou grosseiro, chegando a maior parte do tempo, sem nem se apresentar, para me falar de uma criança para colocar no pensionato, isso me perturbava e durante muitas semanas, muitos meses, fui acometida por uma febre dolorosa, não por que eu tivesse vergonha de meu trabalho, mas porque eu sofria por ter que me fazer conhecer, por não viver unicamente em e para minha família. Depois que a visita ia embora, eu tomava angustiada minha cabeça entre as mãos dizendo: "Meu Deus, dá-me coragem" e se eu tivesse ganho um aluno, acrescentava: "Obrigada meu Deus por teres abençoado meu trabalho" (...) O primeiro dinheiro que colocaram em minha mão para pagar o primeiro trimestre

32 GARDINER, Juliet. (ed.) The New Woman: Women's Voices - 1880-1918. London, Collins \& Browns, 1993. O livro é um conjunto de excertos de fontes sobre de mulheres nesse período. 
Vavy Pacheco Borges

de minha primeira aluna, fez minhas lágrimas escorrerem... Depois, habituei-me pouco a pouco a assinar os recibos sem tremer, a estender a mão para receber o dinheiro leal $e$ penosamente ganho - parece que é uma esmola que lhe fazem mas é preciso algumas vezes lutar demais para recebê-la - que diferença do dinheiro dado por uma mão amiga.

Reclama de ter que ganhar a vida para os sete filhos:

Por eles devo estudar um sorriso amável, estar sempre vestida de maneira simples, mas impecável, tornar minha moradia confortável e agradável. O mundo não gosta de ver uma dor eterna, é preciso mostrar calma e coragem, eu devo viver para o mundo para ganhar o pão de meus filhos, eu devo me fazer a escrava do mundo.

Reclama em especial de ter que lidar com os "livros de contas". O marido não gostava do fato de ela ter que trabalhar e ela concordava com ele:

Pobre querido, meu bem-amado, se eu fosse homem seria como ele, teria tido esse sentimento de delicadeza que o fez sofrer tanto e que talvez o tenha matado, eu também teria querido que minha mulher vivesse em mim e por mim, que ela me devesse tudo, tudo, o desabrochar de sua alma, o despertar de seu coração o fogo de seu amor, os filhos feitos de sua carne, o bem estar de seu ser interior ganho unicamente pelo trabalho dele; se eu fosse homem, teria querido tudo tirar de minha própria força para minha mulher. [Em 1907 escreve que ele morreu por não poder cumprir esse papel] não por motivos de orgulho em relação a outras pessoas, mas por orgulho de amor, essa impotência o matou... [morreu fazendo seu dever de homem] deu a vida para salvá-los [os filhos] da miséria que os perseguia. 
Uma mulher e suas emoções

\section{Concluindo}

Eugénie, de uma forma que parece voluntária, preservou seu diário para seus descendentes; foi em mãos da família de seu filho Georges Leuzinger Masset - o Georginho - que encontrei o diário. Sua sobrevivência psíquica pode, em boa parte, ser acompanhada nesse diário, através do qual ela nos lança uma imagem a ser explorada.

O diário para o historiador é um documento, uma voz, um testemunho. Como em qualquer procedimento de pesquisa histórica, uma visão mais "real" e completa sobre Eugénie Leuzinger Masset, que vá além da imagem e das informações que apenas o diário nos traz, requer uma consulta a outros documentos, vozes, testemunhos, que informem sobre ela.

Uma dessas vozes é de seu filho caçula, Georginho, num manuscrito redigido em português - logo após a morte da mãe, no início do chamado luto freudiano - explicitamente para que os filhos compreendam sua dor e para que tomem a avó como "exemplo de energia, de honradez, bondade e amor". Através de sua neta, Mercedes Lacombe Heilborn, essas notas, assim como o diário, estão preservadas. ${ }^{33}$ Relata o cotidiano da vida deles no Colégio Masset:

[A mãe] Trabalhava dia e noite, das 7 da manhã às 10,11 , 12 e 1 hora da manhã! Dormia n'um grande salão rodeada dos 7 filhos, este salão tinha uma divisão a meia altura, de um lado, o maior, com 3 janelas era o nosso dormitório, do outro o seu escritório com uma só janela. Ali tivemos sarampo, coqueluche, catapora, etc. Tratava-nos a todos não dispensando suas ocupações habituais. Os recursos não davam para enfermeiras, durante o dia as Criadas, que aliás eram poucas, se ocupavam dos doentes e Ela vinha nos ver de tempos em tempos, quando tinha uma pequena

${ }^{33}$ Mercedes, funcionária do Instituto Histórico e Geográfico Brasileiro, é filha do historiador Américo Jacobina Lacombe, genro de Georges Masset. 
Vavy Pacheco Borges

folga. À noite era Ela a enfermeira. Cumpria ao mesmo tempo o dever de boa Mãe, que o foi das melhores, e o dever de bom pai de família, que soube galhardamente substituir (...) [Recapitula as dificuldades financeiras que atravessaram] Vivemos uma infância de muita economia e com vinténs contados, um por um, pois eram ganhos com muita dificuldade e muito trabalho por uma pessoa só (...) Lutou, removeu os maiores impecilhos (...) Pagou a hipotéca da Rua D. Marianna 73 - os 17 contos e mais os juros, até o ultimo vintém, a custa de seu trabalho.

Outra voz é a de seu próprio marido, Gustave Léon. Três das cartas que ele escreveu, na primeira metade dos anos 1870, para sua mãe Betsy Masset na França, atestam o bem sucedido romance dos dois, revivido depois por Eugénie. ${ }^{34}$ Embora o dinheiro não estivesse sobrando na vida do casal, afirma:

Ela é encantadora, minha mulherzinha, e nós nos entendemos perfeitamente bem. Fiz muito bem de não correr atrás de um dote que poderia ter tido com outras, nas quais, talvez, não tivesse encontrado a felicidade que agora experimento.

Conta que vivem somente para os filhos "maravilhosos", fala sobre seu amor por eles, seu cotidiano agradável, dizendo que a recepção do final do dia (descrita no diário tantos anos depois por sua mulher) é a maior recompensa de suas fadigas.

Outros documentos da família Leuzinger - cartas, relatos familiares, processos de herança, álbum de desenhos e fotos dela - podem ajudar a esclarecer a vida e o temperamento dessa mulher do século XIX que foi Eugénie Leuzinger Masset. Mas somente a leitura de seu diário já pode ser um prazer, tanto para seus familiares quanto para historiadores e leitores interessados.

${ }^{34}$ Estavam nos papéis de família de meu marido. São todas em francês; a primeira data de 6-11-1870, a segunda de 21-11-1871 e a terceira de 13-111874. 